\title{
COMMENT
}

\section{POSNER ON DUNCAN KENNEDY AND RACIAL DIFFERENCE: WHITE AUTHORITY IN THE LEGAL ACADEMY}

\author{
JEROME MCCRISTAL CULP, JR.*
}

\begin{abstract}
What then are the tenure standards for the affirmative action hires to be? If they are the same tenure standards as for white males, then probably a disproportionate number of blacks will not make tenure, and this will be more than awkward. What is to be done? Are there to be two tenure tracks? If so, will voting on tenure in the affirmative action track be limited to blacks? 1

There is room for suspicion that people are being excluded for discriminatory reasons (albeit probably unconscious ones), and also for the hope ... that a diversity of approaches ... are desperately needed antidotes to complacency and stagnation. There is some evidence that feminism has had this effect ... maybe minority scholarship will as well.

I think not, myself. And one reason is that whereas feminism is an approach (or cluster of approaches), race is not. . . . The problem $\ldots$ is that not all blacks are culturally black. ${ }^{2}$

Professor Kennedy does not mention a single idea that critical race theory has produced ... . I I think Kennedy's faith that if only more blacks were law professors they would produce a scholarship that would "knock our socks off" is a false and sentimental faith, reflecting a lack of realism that is a constant feature of Professor Kennedy's work .... ${ }^{3}$
\end{abstract}

* Professor of Law and Director of the John M. Ohn Program in Law and Economics, Duke University School of Law. B.A., Umiversity of Chicago 1972; M.A., Harvard Umiversity (economics) 1974; and J.D., Harvard Law School 1978. I would hike to thank Kate Bartlett, Paulette Caldwell, Christopher Schroeder, Jeff Powell, Joe Knight, Walter Delhinger, Jennifer Arlen, Garrett Epps, and David Lange for their helpful suggestions and criticisms. This paper grew out of a discussion I had with Patricia Wilhams while she visited the Duke Umversity School of Law in the fall of 1990, and it has particularly benefitted from conversations I had with Paulette Caldwell while in residence at the New York University School of Law in the fall of 1991. However, any remaining errors are my own. I would also like to thank the New York University School of Law for its generous support during the fall of 1991 .

1. Richard A. Posner, Duncan Kennedy on Affirmative Action, 1990 DukE L.J. 1157, 1159-60 (emphasis added).

2. Id. at $1160-61$ (emphasis added) (footnotes omitted).

3. Id. at 1161 (footnote omitted). 


\section{INTRODUCTION}

Because there are now some black law professors with tenure ${ }^{4}$ it has become possible for black scholars to begin to have an intellectual conversation, to create a Black Legal Scholarship, that is not driven exclusively by concerns of the white majority in American law schools. ${ }^{5}$ The most powerful element of Black Legal Scholarship has been the ability of these scholars to define their own agenda. This proactive component has both positive and negative aspects. Taking control of our agenda provides black scholars with freedom and legitimacy on our terms. This same autonomy simultaneously threatens others, especially some white scholars. Because of the fears generated by Black Legal Scholarship, some majority scholars attack it on the ground that it is not "real" scholarship because it does not speak for an appropriate constituency or deal with appropriate concerns. The unstated but obvious premise is that Black Legal Scholarship is mere special pleading.

The response by Judge Richard Posner to an article by Duncan Kennedy ${ }^{6}$ in a recent issue of the Duke Law Journal is perhaps the most elegant example of this response. Judge Posner's response is the pious, sohpsistic demand of white authority and the right of ultimate control in

4. It is important to understand that tenure may mean less for black people than for white people, particularly white males. For example, see the detenurization of Andrew Haines by William Mitchell Law School after he filed a race discrimination suit. See School's Out, NAT'L L.J., June 12, 1989 , at 6.

5. Several nonwhite scholars formed a group three summers ago to discuss the interplay of race and law. Critical race theory developed out of the writings of these scholars and other nonwhite scholars interested in similar issues. Critical race theory is not uni-perspectival; there is no single consensus of a characterization of the theory. Certainly the name "critical race theory" suggests some connection to critical legal theory, yet its name derives more directly from the name "critical theory" by which some refer to the tenets of the Frankfurt School of Philosophy of Habermas and Marcnse. The contributors to critical race theory have resisted defiming themselves.

I have described similar movements as Black Jurisprudence and Black Legal Scholarship. See generally Jerome M. Culp, Jr., Toward a Black Legal Scholarship: Race and Original Understandings, 1991 DUKE L.J. 39. These movements include more scholars than does critical legal theory, including soine people who do not consider themselves part of the movements. Black Jurisprudence consists of the significant early efforts made by black hitigants and lawyers and the more recent efforts of black judges. See id. at 48-50. Black Legal Scholarship consists of the efforts centered on changing the way we look at the law and empowering black teachers and students. I have focused on the black part of the nonwhite mix for the purpose of self-definition. White Americans who define nonwhite scholars as "other" negatively affect the notion of "people of color." By maintaining the distinctions between the various perspectives of people of color, I hope to encourage everyone to dcal with the differences and sunilarities between the histories of separate racial groups. However, I recognize that all people of color writing on the interplay of race and law and similar issues are joined by our opposition to racial oppression, and I believe that it is possible to build a progressive response to this oppression.

6. See Duncan Kennedy, A Cultural Pluralist Case for Affirmative Action in Legal Academia, 1990 DUKE L.J. 705. 
the legal academy by one of this country's leading academicians and jurists. Judge Posner's Essay is important because, in both tone and substance, it manifests the arrogance and unselfcritical nature of white supremacy in the legal acadeiny. It is the inajority voice, atteinpting to silence black voices. Judge Posner's defense of neutral and objective standards in legal scholarship fails to acknowledge that facially objective and disinterested standards in fact serve the interests of the white majority in the legal academy.

I respond to emphasize that black scholars should reject the claims obhiquely made by Judge Posner about them and their scholarship and that nonblack scholars ought to take care not to perpetuate similar efforts at white authority in different contexts. This Cominent will address those aspects of Judge Posner's claims by discussing first how Judge Posner's assumption of white authority influences his interpretations of scholarship, and then how Judge Posner attempts to use this white authority to define who is black. ${ }^{7}$ I will then articulate what I am and am not saying about the discourse between black and nonblack scholars. I will end this Comment by dennonstrating that simple defenses of Judge Posner's position as neutral and nonracist will not work.

\section{White Authority, RACE, AND Legal ScholarshiP}

The critique of law by people of color is based not on color, but on opposition to racial oppression. Judge Posner does not understand this. Instead, he makes two conflicting and obfuscating claims about this scholarship. First, he claims that using race to find candidates for faculty appointments has led to a diminution in standards. This is an oblique attack on the existence of black faculty in the acadenny. Judge Posner's

7. I cannot resist pointing out, however, the explicit racism in Judge Posner's first quote above. His suggestion that there is a need for an affirmative action notion of tenure is supported neither by the history of tenure by minority scholars at predominately white law schools, nor by the history of tenure by white scholars at such schools. He does not provide support for his claims, and, to my knowledge, there is none. Judge Posner assumes that the standards for white faculty are uniform and uniformly applied. Maybe his experience at Chicago has jaded him. (Although how Chicago could have had uniform standards with respect to blacks or any racial minority is hard to fathom. There have been no minority scholars hired by Chicago, and few considered for tenure during his time as a tenured member of that law faculty.) I suggest that in fact Professor Spann is closer to the truth when he addresses similar claims made by Professors Kennedy and Carter:

Both articles offer elaborate arguments to support the proposition that, among legal academics, blacks are not as good as whites. As someone who teaches at a law school (Georgetown) where the median for black [professors] is higher than the inedian for whites, both in terms of scholarly production and teaching ability, I am understandably skeptical.

Girardeau A. Spann, Reader's Coinment, 1 Reconstruction, No. 2, 1990, at 3, 3 (alteration in original). 
second claim is that the efforts of black and nonblack scholars who oppose racial oppression cannot be successful because race is unlike feminism. Of course race and feminism are different, but the point of both forms of scholarship-Black Legal Scholarship and feninist legal theory-is an objection to the existing order. Judge Posner's effort to conflate claims of race and feminism does violence to the developing scholarship of those attempting to create a scholarship opposed to the traditional description of society, which is warped by racial and other oppressions.

In discussing Black Legal Scholarship, it is important to point out what we are not talking about: We are not talking about an entirely new and alien form of scholarship. Much of Black Legal Scholarship is standard, "normal," and traditional in its structure, methods of analysis, and even where it is published. Thus, my criticism of Judge Posner stenis not from the fact that I am doing calculus and he is doing linear algebra. ${ }^{8}$ Rather, my criticism is that Judge Posner wants to control the assumptions of the debate in either linear algebra or calculus. He demands the right to control those assumptions without dealing with alternative assumptions proposed by black scholars. This demand to control the assumptions underlying the discourse is at the heart of the dispute between Judge Posner and black legal scholars. White scholars often ask black scholars to juinp through some appropriate hoop before they will be histened to by "real" scholars. 9 If black scholars are doing some node of

8. As a number of people have indicated, those scholars doing what others have called critical race theory and what I have called a portion of Black Legal Scholarship have utilized a number of techmiques that are fairly new to the intellectual quivers of legal education. In particular, narrative, autobiography, personal location, voice, and perspective have been used to make different points. The angry objections of my colleagues in the academy to some of this work suggests how powerful these techniques have been, but all of the techniques used by scholars of color have been adopted by white scholars. For example, despite his opposition and criticism of some of the trends in critical race theory, Paul Carrington's latest inanuscript is, in fact, the senior white male equivalent of autobiography and narrative. See Paul D. Carrington, Legal Education in a Time of Moral Excess (1990) (unpublished inanuscript). For my criticism of this effort, see Jerome M. Culp, Jr., Letters From Shoal Creek (unpublished manuscript on file with author) (arguing that Dean Carrington's response is a poor history and a distortion of the true circumstances in American legal education).

9. This point is raised im an important essay by Henry Louis Gates. Professor Gates argues that white critics often require of black scholars what Senator Calhoun required of black slaves:

For John C. Calhoun ... . , who stood firmly to his dying day a staunch advocate of states' rights and as a symbol of an unreconstructed South-the person of African descent would never be a full member of the human community, fit to be anything but a slave, until one individual black person-just one-demonstrated mastery of the subtleties of Greek syntax, of all things! Perhaps fearing that this goal would be too easily achieved, Calhoun later added mastery of the bimomial theorem to his list of black herculean tasks.

Henry L. Gates, Authority, (White) Power, and the (Black) Critic: Or, It's All Greek to Me, in THE FUTURE OF LITERARY THEORY 324, 325-26 (Ralph Cohen ed., 1989). My use of the mathematical example harkens back to Senator Calhoun's requirement that a black person have mastered the binomial theorem. Judge Posner is requiring a similar kind of herculcan task of black legal scholars, 
analysis in legal scholarship improperly, then Judge Posner should demonstrate how.

Judge Posner does not defend the assumptions about racial difference imphicit in his own intellectual discourse. For example, he does not tell us why we ought to assume that the very highly qualified black faculty we recruit to the legal academy are inore hikely to fail than are whites. Behind that view is a set of assumptions that he and inany white scholars make, but he does not defend them in any serious way. ${ }^{10}$ This failure even to engage in discourse presumes that the assumptions that black scholars add to legal scholarship are illegitimate without dealing with them. This presumption is offensive to intellectual discourse. If black scholars have added two to two and come up with five in legal arithinetic, Judge Posner has the burden of demonstrating this mistake of method.

Judge Posner's treatment of claims regarding Black Legal Scholarship is very different from his treatinent of other assertions. In Judge Posner's extensively researched discourse on jurisprudence, he engages other intellectual enterprises much more divergent from his own than

but he is not candid enough even to enunciate it clearly. It is not sufficient for Judge Posuer to say that black scholars should publish about a particular set of issues; black scholars are writing about almost every issue that white scholars are writing about. Nor is it sufficient to say that black scholars have not published in particular journals. See Paulette Caldwell \& Jerome M. Culp, Jr., Scholarship and Pedagogy of Race: Theory, Method, and Practice (unpublished manuscript 1991).

Senator Calhoun's representative view of black people ("Show me one black to my liking and I will overlook the others") seems to have been involved in President Bush's nomination of Clarence Thomas to the Supreme Court. The President, like many white oppouents of affirmative action, evidently believes that if one black person supports his views on affirmative action that insulates him from claims of racism.

10. Latino faculty have "qualifications" statistically similar to those of white faculty. See Michael Olivas, Latino Faculty at the Border, CHANGE, May/June 1988, at 6, 7. Some will contend

- that, although this may be generally true, it is not the case at places like Harvard, Yale, and other elite institutions. The truth, however, is that nonwhite faculty at Harvard and Yale indeed have qualifications that are very similar to those of the white faculty there. All of the black faculty at Harvard and Yale have had distinguished careers as students and as law clerks to prestigious judges; several have advanced degrees and other indicia of "quality." Indced, many of the nonwhite faculty at Harvard aud Yale have distinguished themselves in scholarship not concerning race. See, e.g., Stephen L. Carter, The Trouble with Trademark, 99 YALE L.J. 759 (1990); Christopher EdLEY, JR., ADMinistrative LaW: Rethinking JUdicial CONTrol OF BUREAUCRACY (1990); HaRold H. Koh, The National Security Constitution: Sharing Power After the IranCONTRA AfFalR (1990). Beyond a doubt, the faculties of the inajor elite schools have been enriched by the nonwhite faculty they have hired.

This is not to say, however, that these schools have "done enough" or that there are, for example, no qualified women of color who could be added. Certainly these schools have also lost something when they have chosen not to hire some people of color. I believe, but cannot prove to everyone's satisfaction, that the lost benefits to these schools from some of the appointunents not made with respect to people of color cxceed the benefits foregone in other areas. This is certainly true of my own school. 
Black Legal Scholarship. ${ }^{11}$ His failure to address the assumptions of Black Legal Scholarship is therefore special. It cannot be simply that no black person has met Judge Posner's asserted neutral and objective standards of doing research. Rather, the problein has to be that, no matter what black scholars do, he cannot hear their voices. ${ }^{12}$

It is also wrong to assert that black legal scholars simply attempt to substitute their assumptions for those of the majority of the legal academy. The truth is that black scholars, in attempting to formulate alternative perspectives, are required to deal with the assumptions of the white majority. As members of the legal academy, black scholars must start where nonblack scholars start, but they also add perspectives and redefine the appropriate legal paradigms. Black Legal Scholarship is in this sense a direct challenge to the often singular view of how questions may be approached in law and other related scholarship.

Literary criticism has taught us not only the importance of and the power of the writer, ${ }^{13}$ but also the power of the readers and the interpretive community. ${ }^{14}$ Judge Posner, however, does not consider black people significant either as readers or as members of the interpretive communities. Power in the voice of the author is present in all writing:

11. See Richard A. Posner, The Problems of Jurisprudence (1990).

12. His comment to which $I$ respond bears this out. It was itself a response to Professor Duncan Kcnnedy's article on affirmative action. See Kennedy, supra note 6. Interestingly, though, the debate out of which Judge Posner's paper grew also included Professor Kendall Thomas of Columbia Law School. Professor Thomas, a thoughtful and imaginative person, is black and difficult to ignore. One might think that Judge Posner would feel the need to note, if only in passing, the thoughts of Professor Thomas; but Judge Posner is deaf to Professor Thomas's discussion of the very issue of how Black Legal Scholarship ought to influence scholars. Judge Posner simply chooses not to hear black voices. See Tape of Association of American Law Schools (AALS) Program of Law and Interpretation, held at the AALS Convention (Jan. 1991) (on file with author).

I describe as the "Woody Allen Blues" the idea that race is so powerful that it is better left undiscussed and unobserved. (Woody Allen makes movies without black people, not because he is racist, but because he does not know how to deal with race.) Perhaps Judge Posner suffers from the Woody Allen Blues. Perhaps his failure to discuss race stems from his fear that his discussion of it would not be fair, but I do not hear that concern in this work. He has not been afraid to discuss affirmative action in his scholarship. See, e.g., Richard A. Posner, Democracy and Distrust Revisited, 77 VA. L. REV. 641 (1991); Posner, supra note 1. He addresses the issues of race and the law every day as a federal judge. Thus, in this context, he does not have the luxury of being Woody Allen. Unlike Woody Allen-writer, director, and actor-Judge Posner and Professor Posner has to deal with important and immediate concerns of race in his work as a jurist and scholar.

13. See, e.g., HeNRY L. Gates, Bearing WitNess: Selections from African-AMERICAN AUTOBIOGRAPHY IN THE TWENTIETH CENTURY 3-9 (1992) (describing writers' ability to create themselves); JoanNe M. BraXton, Black WOMEN Writing Autobiography: A Tradition WITHIN A TRADITION (1989) (stating that the genre of black women's autobiography reveals the power of the autobiographical voice in the lives of black women).

14. See, e.g., STANLEy Fish, Is There A TEXT in This Class? 171-73 (1980) (arguing that meaning in texts comes from interpretive communities). 
The power of the author to control discourse is one of the most important aspects of writing. By commenting on the merits of black scholarship without engaging it, Judge Posner attempts to deny to black legal scholars the power to speak or the right to author their own discourse. These assertions of power over voice are central to the white control of black concerns in the law and legal scholarship; this power to control and silence is part of the system of racial oppression in America. It is coimected to the racial violence and to official attacks on black people by pohice officers, judges, and officially sanctioned private imdividuals like Bernard Goetz; only im the miceties of its expression is it separable from the voice of the Klan and white supremacists. When Judge Posner uses his white authority, he speaks not as a lonely white voice in the wilderness, but as the representative of white supremacy.

Judge Posner exercises this white authority in three ways: $\mathrm{He}$ claims the right to define the story that is to be told; he dismisses without any serious consideration the story of black scholars; and he supports his view of this story with the semblance of fact backed by white power. In each of these responses, he is confrontational without confronting black people directly; he is dismissive without admitting the extent to which he actually dismisses black concerns; and he is racist ${ }^{15}$ while claiming to be a neutral observer of racial circumstances in the legal academy.

The heart of white authority $m$ the legal academy is the demand of its proponents to replace a black story told by black participants with a story that excludes the voices and experience of black people. In his response to Duncan Keunedy, Judge Posner both tells a story about black people devoid of black people's experience and tells a tale not to the black legal scholars who are telling their own stories, but to a white supporter of some of the claims of black people. Judge Posner speaks manoa-mano to a fellow white ehte law professor.

15. It is always dangerous to use the term "racist." I use it here with some care to talk about a range of actions by white academicians who dismiss without engaging the voices of black academicians. Some will react to this charge by denying it with respect to Judge Posner and themselves. I respond to this denial in Part IV. There is, however, another danger in raising the issue of racism: I leave myself open to the accusation that what I really mean to do is to silence white concerns about race. It may be, in fact, that some white scholars will be silenced by that fear. Certainly inany white academicians clain and worry about that silencing. I believe, however, that if we do not recognize the racist nature of some of our rcactions, then we are severely limited in our ability to find appropriate reforms. Besides, by not confronting the racism endemic to these circumstances, we risk silencing the voices of blacks and women in the academy. Because I believe that those black and female voices have traditionally been the most likely to have becn ignored and unheard, I am willing to risk that some nonblack scholars will be discouraged by this response. I have no fear that all or even most nonblack scholars will not speak on these general questions. 
At the beginning of his response, Judge Posner claims the right to author the contours of the discourse about affirmative action: "Affirmative action-more bluntly, reverse discrimination-is a vast and variegated subject."16 What does he mean by reverse discrimination? Does he deal with this vast and variegated subject in all of its subtleties? The answer is no. Instead, he tells a different story: He makes the central issue of hiring black faculty whether it risks unfairnesses to white faculty. This inquiry is very different than whether some black faculty ought to be included in the pool of potential candidates. Judge Posner's story is the story of black hiring from the perspective of the white majority. Judge Posner's demand is to look at the hiring in American law schools from the point of view of how inuch change white faculty will have to endure. This is not the issue black scholars find important. They have argued that, at least in some situations, it is necessary to look at this issue from the perspective of black faculty. Judge Posner does not and cannot admit that there is another perspective. If he did so, he would have to give up his right to tell the story-to be the author of the discourse. The best example of this change of focus is Judge Posner's question of whether only black faculty ought to be qualified to judge the "affirmative action" hires. ${ }^{17}$ The reality of American legal education-where almost all of the faculty are white inales-makes this question idiotic. The truth is that white control of who becoines a member of the legal academy is for black faculty an uncomfortable reality. My experience and the experience of many black faculty is that there is little relaxation of that control by white faculty. Judge Posner mocks the modest intrusion on this white authority by the very small number of black tenured faculty.

Just as Judge Posner tells the story of black hiring from the perspective of the white inajority, he insists that black civil rights law is not the product of the black lawyers and black chents who produced it. ${ }^{18}$ Judge Posner imsists on including the white lawyers and judges as participants in the creation of civil rights law, but he is not consistent in his view of who counts. Just as black students and professors are seldoin seen as participants in the legal academy outside of civil rights law, black citizens who bear the costs of change do not matter to Judge Posner, as they often do not matter to other federal judges. ${ }^{19}$ Judge Posner cannot allow

16. Posner, supra note 1 , at 1157 (emphasis added).

17. See id. at 1160 .

18. See id. at 1161 ("[The notion that] modern civil rights law is the creation of black lawyers (rather than of black lawyers plus white lawyers plus white judges plus white legislators)" is one of Duncan Kennedy's "fantasies.").

19. See, e.g., Wygant v. Jackson Bd. of Educ., 476 U.S. 267 (1986) (failing to consider the interests of black teachers given superseniority to maintain racial balance in teaching ranks). For further discussion, see Culp, supra note 5. 
black participants to control even civil rights law because it would mean that he has lost his control. ${ }^{20}$ Black (and increasingly nonblack scholars) have the right to claim that civil rights law is a product of a historic and difficult effort waged significantly by black lawyers, with only modest contributions of white lawyers. This effort to change the way in which law saw and treated black people could not ignore white people, but it was about using black experience covertly to influence the law. ${ }^{21}$ If Judge Posner's assertion that civil rights law is controlled by the reactions of white judges and lawyers is the only way of examining the world, then Judge Posner has really concluded that it is not possible for black people to do anything uncontrolled by white mterests.

To control the nature of the debate in legal scholarship, Judge Posner also uses the notion of status quo. He beheves that the status quo is a neutral beginning place from which to look at affirmative action. Every change, every move made by anyone, starts from the view that the world as it is isn't so bad. This starting poimt is easy for the majority to accept, but for many who are not in the inajority - particularly for those who are seldom among the temporary majorities that get to decide ${ }^{22}$ - this is an

20. This effort at control also exists in some white authors very different from Judge Posner. Mark Tushnet's book on the early history of the NAACP antisegregation strategy suffers from a similar effort at belittlement of black participation and aggrandizement of white efforts. Tushnet suggests that black lawyers were absolutely disorganized and controlled by their class and backgrounds. See Mark V. Tushnet, The NAACP Legal Strategy Against SEgregated EduCATION, 1925-1950, at 35 (1987) ("Thus, although [Charles] Houston was responsible for the conduct of what at some points had been thought of as a systematic and coherently organized hitigation campaign, he was more comfortable with pinpoint activities."). Professor Tushnet suffers from the same disease of wanting to control the agenda, here the history, of black lawyers. Tushnet goes on to criticize Justice Marshall as well, concluding that it was Marshall's commitment to competitive individualism that led to his decision to go for broke in the campaign for racial equality. However, as Marshall's career has shown, he was also always committed to a vision of community and support that did not rest on that individualism. Tushnet attributes to Marshall a simple caricature of reality to be able to make the larger claim about what could have been accomplished. It is not that the efforts of Marshall and Houston should not be criticized, but that the criticism should understand the power of change and revolution in its own terms that it represented.

This effort at control is part of a systein of racial power, but even scholars of color are not immune from such criticisms. Does Professor Delgado really pay attention to scholars of color in his article about the imperial scholar? See Richard Delgado, The Imperial Scholar: Reflections on a Review of Civil Rights Literature, 132 U. PA. L. REv. 561 (1984). Indeed, I question whether I use enough of the works of scholars of color myself. None of us is totally free of the remnants of racial oppression.

21. See Jerome M. Culp, Jr., Autobiography and Legal Scholarship and Teaching: Finding the Me in Legal Academy, 77 VA. L. REV. 539, 544-52 (1991) (describing the "transformative power" which results from considering personal experiences of blaeks).

22. Leslie Friedman Goldstein describes this Madisonian view of the American political systein this way:

The [Madisonian] theory propound[s] at least three new techniques for cliecking or preventing majority tyranny. First, the populace is purposefully diversified and dispersed over a large and variegated territory, which fact makes less probable the formation of a 
insufficient beginning. Consider Judge Posner's discussion of the right of black legal scholars to be members of the academy. ${ }^{23} \mathrm{He}$ inplicitly assumes that the assumptions and initial distributions of resources that brought the legal academy to where we are is sufficiently just to be assailable only by overwhelming contrary proof. Black people do not start with this assumption; nothing in logic or legal analysis requires such a beginning. Thus, the status quo is really white authority disguised as neutrality. It is this view of white authority to which Judge Posner's scholarship continually returns.

All authors exercise some power in their writing, but Judge Posner's criticism has a discomforting point to it that goes beyond traditional discourse. He not only does not understand or use the stories told by black scholars, but he disinisses their ability or their right to tell a story at all. What are we to make of an article that disinisses the contribution of black scholars to the legal academy but does not cite the works of black legal scholars?24 Unlike the important contributions of feminism that Judge Posner admits have influenced the law of rape, ${ }^{25}$ pornography, ${ }^{26}$ and sexual harassment, ${ }^{27}$ Judge Posner argues that Black Legal Scholarship has not contributed anything important to the legal academy and probably will not. ${ }^{28}$ Also unlike feminism, where Judge Posner has taken the opportunity to discuss and argue with feminists about what they think, ${ }^{29}$ he has never thought that anything said by a black scholar was worthy of comment. ${ }^{30}$

stable majority coalition. Because the coalition is unstable from one issue to the next, everyone is tomorrow's potential ally, and thus all should recognize that it is expedient and prudent to avoid oppressing anyone or any group.

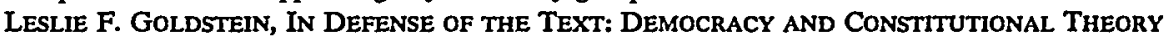
157 (1991) (footnote omitted). African Americans often have not been able to become part of these temporary coalitions either because of white solidarity and racial animus or because of legal restraints that limited the right of blacks to vote.

23. See Posner, supra note 1 , at 1160-61.

24. The one black person cited by Judge Posner is Thomas Sowell. See Posner, supra note 1, at 1157 n.2.

25. See Richard A. Posner, Conservative Feminism, 1989 U. ChI. Legal F. 191, 207.

26. See Richard A. Posner, LAW ANd Literature 334-36 (1988).

27. See Richard A. Posner, An Economic Analysis of Sex Discrimination Laws, 56 U. CHI. L. REv. 1311, 1331-32 (1989).

28. See Posner, supra note 1 , at 1160 .

29. See Posner, supra note 25.

30. You may think I exaggerate this tendency in Judge Posner, but in his latest and quite extensive work on jurisprudence, see POSNER, supra note 11 , he discusses almost every trend in the legal academy, but does not discuss the claims of black legal scholars in any serious way. He does cite to an important effort on the part of mimority scholars in the Harvard Civil Rights Civil Liberties Law Review, see id. at 405 , for the narrow proposition that marginal groups will suffer unfairly if some rights are removed; but that is the ouly citation to black or minority legal scholars in the bool: Almost every other important current (and a few not so current) strand in the legal community is discussed. Why not Black Legal Scholarship or critical race theory? The reason is simple: For 
It is interesting that Judge Posner would take this view. Even with respect to feminism, one of the most important trends in recent years is the claim made particularly by black and other minority feminists that they are "left out." The feminist cominunity has responded by trying to include the concerns of nonwhite women and other "marginal" women mside their discourse. ${ }^{31}$ Judge Posner, however, does not cite any of this scholarship even when he comments on feminism in a conference volunie that includes the voice of at least one black woman. ${ }^{32}$ Black women who write as feminists in the legal acadeiny are just as mvisible to Judge Posner as are black legal scholars in general.

It is hard to believe the hubris im Judge Posner's ignoring of black voices in legal scholarship. The footnotes in his books make clear that he keeps up witli the trends in legal scholarship. He could not have failed to read Professors Derrick Bell, Charles Lawrence, Patricia Williams, Angela Harris, Kimberlé Crenshaw, and Randall Kennedy. He must have considered and dismissed the powerful call of Charles Lawrence for law to take account of unconscious racism..$^{33} \mathrm{He}$ could not have missed the powerful epistles of Patricia Williams on race and contracts and race and criminal law. ${ }^{34}$ Even if he reads ouly the "best" law reviews, he could

Judge Richard Posner and much of the largely white male legal academy, the claims of black and minority scholars about how race and the law intersect do not exist. Blacks and minority scholars are not a part of the discourse. Judge Posner therefore does not have to say why the claims of black scholars about race and law are not successful, because, again, he has not heard their voices. I do not mean that he has not rcad what they write, but that he cannot process it into something that makes sense in his epistemology. Racial differences inatter only when they are so urimportant that they will not influence anything that is important. See also Jerome M. Culp, Jr., The Education of Judge Posner?, Transition, Iss. 52, 1991, at 114.

31. See, e.g., Kimberlé Crenshaw, Demarginalizing the Intersection of Race and Sex: A Black Feminist Critique of Antidiscrimination Doctrine, Feminist Theory and Antiracist Politics, 1989 U. ChI. Legal F. 139 ("I have chosen this title as a point of departure in my efforts to develop a Black feminist criticism because ir sets forth a problematic consequence of the tendency to treat race and gender as mutually exclusive categories of experience and analysis."); Angela Harris, Race and Essentialism in Feminist Legal Theory, 32 STAN. L. Rev. 581 (1990); DEBORAH G. WhITE, AR'N'T I A Woman? Female Slaves in the Plantation South 13-61 (1985); Elizabeth Spelman, Inessential Woman: Problems of Exclusion IN Feminist Thought (1988):

It is not news that dominant Western Feiminist thought has taken the experiences of white imiddle-class women to be representative of, indeed normative for, the experiences of all women. Much of such thought, it is now common to say, expresses and reinforces the privilege of white middle-class women: their lives and works, their griefs and joys constitute the norm in relation to which other women's lives-if they are inentioned at all-are described as "different."

Id. at ix.

32. See Posner, supra note 25. This issue includes the article by Crenshaw, supra note 31 .

33. See Charles R. Lawrence III, The Id, the Ego, and Equal Protection: Reckoning with Unconscious Racism, 39 STAN. L. Rev. 317 (1987). Judge Posner inust also have inissed or ignored the growing list of scholars who have used Professor Lawrence's work in their own. See, e.g., Sheri L. Johnson, Unconscious Racism and the Criminal Law, 73 CoRNELL L. REV. 1016, 1031 (1988).

34. See Patricia Williams, The Alchemy of Race and Rights (1991). 
not have missed Randall Kennedy's questioning of the celebration myth in constitutional history scholarship. ${ }^{35}$ Indeed, we know that the Harvard-educated Judge Posner inust have read Professor Bell's chronicle when it was the Foreword to the Harvard Law Review. ${ }^{36}$ Judge Posner cannot plead ignorance.

Even the imtellectually innocent cannot have missed the contributions of minority scholars, particularly black scholars, ${ }^{37}$ to the debate about the contours of hate speech. ${ }^{38}$ Black scholars have not been alone in trying to persuade the colleges to change what they do, but they, along with feminists and other allies, have done to that area of the law what feminists did to discussions of rape and sexual harassment: They have begnn to move the courts and scholars on this issue. ${ }^{39}$

This inovement, however, has a larger history, one connected to the way in which law has treated the voice of black people over time. Judge Posner's way of dealing with black voices-ignoring them-is not new. Before slavery was abohished in the United States, slaves made various efforts to free themselves. In New York City, then one of America's largest arenas for black slavery, an alleged conspiracy took place that led to the death of a number of white citizens. Because the allegations included the actions of both white citizens and black slaves, the government provided trials. ${ }^{40}$ In these trials, black defendants were not allowed to take the oath and of course could not testify. ${ }^{41}$ The fate of these black slaves was ultimately decided in silent ignorance of the black stories they possessed. Just as the colomal governments chose not to hear black slaves, Judge Posner cannot hear black scholars. Their reasons are exactly the same: Colomal American whites thought that black slaves lacked the moral fiber to tell the truth and the inental ability to know what it was. Similarly, white scholars like Judge Posner believe that black voices lack

35. See Randall Kennedy, Race Relations Law and the Tradition of Celebration: The Case of Professor Schmidt, 86 Colum. L. REv. 1622 (1986).

36. See Derrick Bell, The Supreme Court, 1984 Term-Foreword: Civil Rights Chronicles, 99 Harv. L. Rev. 4 (1985). A slightly expanded version of this essay appears in book form. See Derrick Beli, ANd We ARe Nor Saved: The Elusive Quest for Racial Justice (1987).

37. In another article, I address the larger question of the contributions of black legal scholars to legal scholarship. See Culp, supra note 5 (arguing that black law professors are beginning to develop a distinct racial perspective on the law, but that this perspective is limited by the ability of white power brokers to hear it and the willingness of black scholars to be outside the mainstream).

38. See, e.g., Charles R. Lawrence III, If He Hollers Let Him Go: Regulating Racist Speech on Campus, 1990 DUKE L.J. 431.

39. See Frontiers of Legal Thought II: The New First Amendment, 1990 Duke L.J. 375-586.

40. Trials were not required for blacks, but were required for white conspirators. In 1741 in New York, any judge or inagistrate could decide the fate of any black slave before any five freeholders. Thomas J. Davis, A Rumor of Revolt: The Great Negro Plot in Colonial New YORK 55 (1990).

41. Id. at 56. 
the moral (neutral and disinterested) perspective of white scholars on black issues, and that black scholars in general are too vacuous to add anything to the discourse. White scholars hike Judge Posner would rather speak to other white scholars about black legal scholars than speak to black scholars theinselves. Black issues that affect black citizens are being decided without listening to the scholarly voices of black legal scholars. It was not defensible in 1741 to fail to listen to the black stories black people wanted to tell; it is no inore defensible now.

To make the point even more clearly: Could Judge Posner discuss feminism without discussing one woman author, or law-and-economics without discussing the work of one person trained as an economist and claiming to be doing such scholarship? He would be embarrassed to produce such criticism. How can he not be einbarrassed with respect to black scholarship? The only answer is that Judge Posner believes that black people caimot speak and defend themselves in a distinctive way. Their voices are important only when they echo what white scholars have said or will say. Black scholars cannot cede this authority to white scholars without becoining a inodern version of black slaves-silent, unheard, and powerless-in this inodern discourse about race and the law.

\section{White Authority ANd the Black Question}

Judge Posner tells us that all black people are not really black. Some have become, to paraphrase Kenneth Stampp, white people with black skins, nothing inore and nothing less. ${ }^{42}$ Judge Posner claims the right to say that a black who is not "culturally black" calmot speak or comment froin a black experience because she does not share a unique experience with other black people. ${ }^{43}$ The problein is that Judge Posner will not permit black scholars to define theinselves. Judge Posner reserves to himself the authority to define whose voice inatters. Soine blacks scholars will deny either the possibility of speaking with a black voice, ${ }^{44}$ or, while acknowledging that some black people can speak with

42. See Kenneth Stampp, The Peculiar Institution (1954):

I have assumed that the slaves were merely ordinary human beings, that innately Negroes are, after all, only white men with Black skins, nothing more, nothing less.*

*I did not, of course, assume that there have been, or are today, no cultural differences between white and black Americans. Nor do I regard it as flattery to call Negroes white men with black skins. It would serve my purpose as well to call Caucasians black men with white skins.

Id. at vii. In between the hardcover and the paperback editions of this book Professor Stampp added the above footnote to respond to those who thought, even before "multicultural" and "politically correct" were dominant terms, that his comment was insulting to black people.

43. Posner, supra note 1, at 1161.

44. See Randall L. Kennedy, Racial Critiques of Legal Academia, 102 HARv. L. Rev. 1745 (1989) (arguing that black and other minority scholars have not made a case for their exclusion from 
such a voice, will decline to claim such a voice. ${ }^{45}$ However, those choices are made by those black scholars who use their own authority to define theinselves. Judge Posner claims the exclusive authority to decide what is important in black voices and how it is to be used. He does not want to permit a black person who has not suffered "enough" discrimination or acquired "enough" black slang to bring her black experiences to the legal academy. Judge Posner is therefore claiming the right to decide what is important about black people. This strange claim of white authority has a catch-22 quality. If black people decide that they are black, then their views are too unimportant and divergent to be included; if they decide to reject the exclusive black experience, then they offer nothing that white scholars cannot bring to the discussion. It reminds me of the headline from a recent New York Times: Poll Says Most Blacks Prefer "Black" to "African-American." 46 The question posed to black Americans was what would they like to be called. Authors of the question, however, have to decide who is black: Who gets to answer the question? A similar cultural agreenient is at stake for black Americans in being polled about their name and in deciding whether they will do Black Legal Scholarship with a black voice. Leshe Espinoza reminds us that naming is important and limiting to the opportunities of iminority scholars. ${ }^{47}$ But denianding the right to name-to control the categories of discourse-is what white authority is all about. Judge Posner is full of this claim here.

The effort by Judge Posner to claim the right-the power-to decide who is black is the ultimate use of the same white authority that is used

the academy or proven that they have a distinctive voice). But see Culp, supra note 5, at 90-91 (stating that Randall Kennedy is one of several black scholars who have begun to speak with a black perspective); see also Robin D. Barnes, Race Consciousness: The Thematic Content of Racial Distinctiveness in Critical Race Scholarship, 103 HARV. L. REv. 1864 (1990); Richard Delgado, Mindset and Metaphor, 103 HARV. L. REV. 1872 (1990); Leshe G. Espinoza, Masks and Other Disguises: Exposing Legal Academia, 103 HaRV. L. REV. 1878 (1990).

45. See Alex M. Johnson, Jr., Racial Critiques of Legal Academia: A Reply in Favor of Context, 43 STAN. L. REV. 137, 137 (1990) (noting that he himself is a scholar of color who does not write from a black perspective); see also Stephen L. Carter, Academic Tenure and "White Male" Standards: Some Lessons from the Patent Law, 100 YALE L.J. 2065 (1991):

I am troubled by the increasing number of academics who seem very serious about the idea that knowledge of the author's race helps create a better context for understanding the author's argument, not just on subjects relating to race, but on other subjects as well; ...

[D]id I hide my true and best voice, the voice of color, under a patina of whiteness?

Id. at 2066. But see Jerome M. Culp, Jr., Voice, Perspective, Truth and Justice: Race and the Mountain in the Legal Academy (forthcoming Loyola Law Jourual 1992) (stating that it is not possible for black scholars to be seen as being without their racial context).

46. Poll Says Most Blacks Prefer "Black" to "African-American," N.Y. TIMEs, Jan. 29, 1991, at A19.

47. See Leslie Espinoza, Labeling Scholarship: Recognition or Delegitimation, 5 ST. LouIS U. PuB. L. REV. 197 (1991). 
to limit the black voices heard in the legal acadeny. ${ }^{48} \mathrm{I}$ believe 1nost black scholars would reject the way that Judge Posner views blackness. At least from my perspective as a black legal scholar, Randall Kennedy, who may have had cultural experiences different than mine, is still black. I am sure he is reminded of his blackness every day. I cannot escape being a black law professor, whether or not I accept the limiting consequences of the way our society views blackness, and whether iny parents are upper-class doctors or coal miners. ${ }^{49}$ This does not mean that black scholars are indifferent to the views of the blacks who are chosen to represent black concerns, but this is no more true of black scholars than it is true of law-and-economics scholars.

\section{You'RE TOO SENSITIVE}

Some will see this Comment as too sensitive to the casual comments of a white scholar about affirmative action. Indeed, some will have noticed that in this response I have concentrated on the white/black controversy and will wonder whether I am being fair to this debate. Judge Posner makes clear that he is concerned primarily with the issue of black relations with the dominant white society. ${ }^{50}$ This view of affirmative action as a "black" concern is not new. It is clear that a majority of people who think about affirmative action do so with a model of a black participant as the focus. This mythic story illuminates and obscures important issues in this debate about race and the law. Most affirmative action plans include not just black students, workers, or contractors, but also members of other racial groups (and women) who have historically been discriminated against. 51 How is one to explain this inclusion of groups who are not black if our model of racism and what needs to be remedied is concentrated on blacks? If we focus instead on the participants who

48. I want to note that Judge Posner's suggestion that there are few people who could be law professors requires questionable assumptions. The available evidence supports the view that there are many more people out there than we are finding who could do what we do. Many successful academicians were not at the top of their class, nor did they have any of the other indicia of success, whereas a number of academicians who had all of the "right" criteria did not make it.

49. See Culp, supra note 21 (I and many other black law professors use our backgrounds to educate our students.).

50. See Posner, supra note 1, at 1159. Judge Posner does not tell us exactly how he would picture himself in this context, but he clearly identifies with the dominant majority culture. I will call this dominant culture "white society" and will speak about the white/black conflict here, ignoring the multiconsciousness of Judge Posner because in this context he does not call on it.

51. The Supreme Court in City of Richmond v. J.A. Croson Co., 488 U.S. 469 (1989), mocks the Richmond City Council's efforts to imclude a wide array of groups in its set-aside program, and in passing suggests that a black majority on the city council makes the use of race more suspect because, unlike traditional situations, this group is helping itself. See id. at 495-96. I should note in passing that this makes two assumptions supported neither in the record nor in the recorded history of racism in America. First is the claim that only blacks are helped by these programs. This is 
are women or Asians, it becomes harder for the people concerned about affirmative action to assume the racial inferiority of the participants. By saying that I do not mean either to participate in the denigration of black participants in affirmative action or to suggest that our majority culture does not hold strong and significantly debilitating views about women or Asian men and women. However, at the heart of the concern with affirmative action as a black concern is almost always a belief in the intellectual and cultural inferiority of black people and an almost religious zeal not to overcompensate the victims of racial oppression. Even when the costs of affirmative action are spread very broadly, racism imbedded in our society makes people react against its implementation. How else can one explain statements by those who say they are opposed to "affirmative action plans" like Pell Grants and food stamps? ? $^{52}$ Of course, these people confuse racially neutral class-based awards with affirmative action. ${ }^{53}$ These responses suggest that what is really at stake is not reform, but rather any change in the racial status of black people.

Nor is the Supreme Court immune to these concerns. Justice O'Colmor's solicitude in City of Richmond v. J.A. Croson Co. ${ }^{54}$ for the white contractors who do not have the right to have total control over the contracts in Richmond is not matched by any real sensitivity to the phight of the nonwhite contractors who have been perpetually locked out by the system of racial control in our society. Indeed, the Croson Court exhibited a form of myopia, seeing the world through the lens of the majority and relegating the concerns of black contractors to the unimportant and unexamined fringe. This inyopia is not new; it is reflected in cases as diverse as Dred Scott v. Sandford ${ }^{55}$ and Wygant v. Board of Education. ${ }^{56}$

demonstrably untrue. Second, the court implicitly ignores the import of the inclusion of other people of color and women in the classification. You cannot criticize a "black" city council for racial nepotism when they have included a majority of the people in the country in their program.

52. See, eg., Joseph Berger, Deep Racial Divisions Persist in New Generation at College, N.Y. Times, May 22, 1989, at 1. My favorite example of campaign rhetoric is David Duke's statement in his campaign for senator from Louisiana. Mr. Duke, a former head of one of the Ku Klux Klans, founder of the National Association for the Advancement of White People, and a statc representative, wondered wistfully when there would be a white Miss America again. Linda Witt, Political Rockin' ' $n$ ' Rollin', Gannett News Service, Nov. 7, 1990, available in LEXIS, NEXIS Library, GNS File. (Two of the last three Miss Americas have been African Americans, including one of my former Duke Law students.) Many white Americans implicitly see law in the way David Duke sees Miss America: something that belongs to white framers, white founders, and white intellectual concern. See Culp, supra note 5, at 77-80. based.

53. Pell Grants are need-based awards for post-high school education. The awards are not race

54. 488 U.S. 469 (1989).

55. 60 U.S. (19 How.) 393 (1856).

56. 476 U.S. 267 (1986). 
The same is true even in the legal acadenn. When Mark Tushnet, a critical legal scholar of the first rank, suggests in his retrospective on the Critical Legal Studies (CLS) inovernent that the acadeiny has hired racial minorities without appropriate pohitics instead of white inales with appropriate pohitics, ${ }^{57} \mathrm{I}$ hear echoes of white supreinacy masquerading as radical politics. ${ }^{58}$ In contrast to Professor Tushnet's claim about the

57. See Mark Tushnet, Critical Legal Studies: A Political History, 100 YALE L.J. 1515 (1991):

The analysis ... indicates that the following priorities will occur in hiring decisions: (1) mainstream white males; (2) "mainstream" women and minorities (the scare quotes indicating that women and minorities are necessarily out of the inainstream in some respects no matter what their scholarship or overt political affiliations); (3) woinen and minorities who identify with the Left, including those who present themselves as affiliated with cls; (4) white males who identify with the Left, including thosc who present themselves as affiliated with cls. (Because the criteria by which conservatives are evaluated differ from the ones discussed here, I cannot readily locate thein on the scale just presented.) Thus, I do not suggest that of those associated with cls only white inales are underrecognized, but only that structural reasons are likely to lead to a systematically greater amount of underrecognition of white males associated with cls.

Id. at $1541 \mathrm{n} .100$. This view of the state of hiring and tenure at universities and the problem of diversity is shared by a wide variety of people, including the inainstream, who see themselves under attack froin the left and from women and people of color. Thomas Morgan noted:

Climical law teachers ... often see themselves as a distinct minority within legal education and vigorously assert claims to better treatinent. Legal writing teachers often express a similar view, as do some legally-trained hbrary staff ineinbers.

... Untenured faculty often see themselves as in a hostile world, intimidated rather than nurtured by senior colleagnes. Faculty who teach interdisciplinary courses also find themselves in a minority and complain of little understanding of the competing pulls of their disciplines.

Thomas B. Morgan, President's Message: The Challenge to Maintain Diversity in Legal Education, Ass'N AM. L. SCH. NewsL., Nov. 1990, at 1, 1. The truth is more complicated, however, and, despite some modest progress by women and to a lesser extent by people of color, Professor Tushnet's view of the academy is not a reflection of the faculty ineetings and tenure fights $I$ have observed at two law schools as a nember of the faculty and a few others as a visitor.

58. These echoes grow stronger as Professor Tushnet's reflective paper on critical theory derigrates those of color who have made contributions and ridicules the methods they use, even as Professor Tushnet uses them:

In hight of the content of critical legal studies, I imagined as well that the form of the presentation ought not be the standard expository essay. On reflection, however, I concluded that, though I had to avoid the expected content, I could not depart from the standard form.

Id. In a footnote, Professor Tushnet then explained his rationale underlying "could not":

"Could not," because of iny concern that departures from the standard form require a degree of techmical competence in writing that I lack. I have been uncomfortable with the publication of law review articles in the form of short stories, or short stories in the form of law review articles, because they strike me as yet another manifestation of the "lawyer as astrophysicist" mentality that I have criticized. See Mark V. Tushnet, Truth, Justice, and the American Way: An Interpretation of Public Law Scholarship in the Seventies, 57 TEX. L. REV. 1307, $1338 \mathrm{n} .140$ (1979). This was brought home to me in a conversation with a former roommate, now a professor of literature, in which iny wife and I were trying to identify the author of a line of poetry quoted in a newspaper puzzle. My friend immediately began by saying something like, "Well, it couldn't be by $\mathrm{X}$ because the line is too long for him." I realized then that there is a world of understanding about literature to which I essentially have no access, and I now wonder about the degree to which other law professors do. The cynical version of this point is that if law professors could write short stories, they would be short-story writers rather than law professors. On the other hand, my cynicism is tempered by my recollection of the short stories my father wrote. After he retired from medical practice, he wrote what I think of as Jewish science fiction. He was not a 

most traditional sense, the way in which white scholars respond to the scholarship of black scholars.

\section{Posner's Not a Racist: WhIte AUthority MASQuerading AS NEUTRALITY}

I am sure that some of Judge Posner's friends will contend that I have unfairly pictured him as a racist. Judge Posner, they will say, may be wrong or wrong-headed, but he is not a racist. He may be much too concerned with how economic constraints limit the law, but he is not a racist. These friends will point out that he has spoken out on the bench against racism - sometimies in poignant ways. ${ }^{61}$ These same friends will no doubt point to the occasional kindness of Professor Posner to black students or colleagnes. I am sure some of Judge Posner's friends will be black and will testify to Judge Posner's genuine friendship and bonhommie.

I doubt none of these testimomials, and indeed I assume them in advance to be a true and accurate picture of the "real" Judge Posner. This Judge Posner is not the caricature who wants to sell babies, ${ }^{62}$ but the Judge Posner who genumely cares about people, his wife, his children, and society. Judge Posner is a good person and has done many good acts. To me, this "real" Judge Posner, however, is no different than the white slaveowners in the antebellum South who were kind to their slaves (some of the males genumely loved and indirectly married black female slaves) or the white southerner who is particularly kind to "Uncle Joe" or "Aunt Susie," or the white northerner who patromzes her black friends. These people are not intrinsically, eternally, or completely bad people. They deinonstrate real kindness to the black people with whom

61. See, e.g., United States v. Town of Cicero, 786 F.2d 331, 334, 337 (7th Cir. 1986) (Posner, J., concurring and dissenting):

The record compiled in the preliminary injunction hearing makes the strongest case for violation of Title VIl on a "disparate impact" theory that I have seen in my four years of judging. ... The black people whom these ordinances exclude from public employment in Cicero cannot be identified, hence cannot be made whole by an award of damages.

But see Britton v. South Bend Community Sch. Corp., 775 F.2d 794 (7th Cir. 1985) (Posner, J., dissenting):

Although man does not live by bread alone, neither does he live by self-esteem alone, and it is small comfort to a person who loses his job as a result of discrimination in favor of a black to be told that he has, after all, the consolation of being white, that most of the people who have discriminated against him are themselves white, and that he may get his job back some day soon-though some of these plaintiffs have been waiting for three years. I am willing to accept that the equal protection clause means as a practical matter less for whites than for blacks but not that it means nothing at all, which if this decision stands will be the approximate situation in this circuit after today.

Id. at 821 .

62. Richard A. Posner, Adoption and Market Theory: The Regulation of the Market in Adoptions, 67 B.U. L. REv. 59, 59 n.1 (1987). 
they interact, but they also deinand the right to decide when a black person is "out of place." In the antebelluin South, black slaves could enjoy real kindness, but a mistake of form could lead to harsh punishment-even death. Similarly, in this society, within iny lifetime and still too often today, black persons who violate the codes of propriety find themselves subject to puinshment, both official and unofficial. Judge Posner's kindnesses are no different. He demands the authority to decide, to be the white power in the legal acadenn. It is this demand, this assertion of pure white supremacy, that black scholars must reject in the claims of their colleagues. 